\title{
SYNTHESIS AND RADICAL POLYMERIZATION OF CYCLOALKYL-SUBSTITUTED METHYLENEDIOXOLANES
}

\author{
F.Kh.Yusifli ${ }^{1}$, G.A.Ramazanov ${ }^{1}$, A.M.Guliyev ${ }^{2}$ \\ ${ }^{\text {I}}$ Sumgait State University \\ 43 quarter, Sumgait, AZ 5008; e-mail: feride-yusifli@mail.ru \\ ${ }^{2}$ Institute of Polymer Materials of Azerbaijan National Academy of Sciences \\ 124, S.Vurgun str., Sumgait, AZ 5004, e-mail:abasgulu@yandex.ru
}

Received 16.03.2020

Accepted 08.05.2020

\begin{abstract}
A number of unsaturated 4-methylene-1,3-dioxolanes were synthesized and described and their polymerization carried out in the presence of radical initiators both in mass and in solution. It has been established by data of $I R$ and PMR spectra of the obtained polymers that the homopolymerization of the synthesized monomers proceeds both with the simultaneous participation of a methylene double bond and a dioxolane cycle with the formation of linear structural links with ketoester fragments, and only with the participation of a methylene group with the formation of links with dioxolane cycles as side groups. It has been revealed that the ratio of forming linear and cyclic structural links depends on monomer concentration and polymerization temperature. It has been established that with increase ofthe monomer concentration during polymerization in solution, the fraction of cyclic elementary links is increased, but in all cases of polymerization, the fraction of linear links prevails over the cyclic one. It has been found that with increase of the polymerization temperature, the fraction of links with the opening of the dioxolane cycle in the macrocycleis increased. The kinetics of the polymerization process was studied, and the reaction orders on monomer and initiator revealed, and the activation energy of the process was calculated. The lower value of the reaction order on monomers in comparison with polymerization of vinyl monomers was explained by availability of two various types of growing radicals in the system and their participation in the chain break reactions.
\end{abstract}

Keywords: methylenedioxolane, synthesis, radical polymerization, initiator, kinetics, polymerization with cycle opening.

DOI: $10.32737 / 2221-8688-2020-2-222-228$

\section{Introduction}

At present, the polymerization of cyclic monomers taking place with the cycle opening, attracts special attention of researchers from both theoretical and practical points of view. This was explained as being due to the fact that such polymerization allows obtaining new polymers with unusual structural links and little accessible or practically inaccessible usual methods of the vinyl monomers polymerization [1-8]. With that consideration, we synthesized new cyclic monomer compounds from the class of methylenedioxolane compounds.

As the initial monomers for polymerization, 2-methyl-2-cyclopentyl (1), 2methyl-2-cyclohexyl (2), 2-cyclopentylidene (3) and 2-cyclohexylidene-4-methylene-1,3dioxolanes (4) have been used. They have been synthesized by dehydrochlorination of the corresponding chloromethyldioxolanes.

\section{Experimental}

The IR spectra were taken on device "Cary 630 FTIR" of firm Agilent Technologies (crystal $\mathrm{ZnSe}$ ). The PMR spectra were taken on spectrometer "Fourier" (frequency - $300 \mathrm{MHz}$ ) 
of firm "Bruker" in CCl4 solution, internal standard - hexamethyldisiloxane, the chemical shifts of signals are presented in a scale $\delta(\mathrm{ppm}$.). The purity of the synthesized compounds was

Synthesis of 2-methyl-2-cyclopenthyl-4chloromethyl-1,3-dioxolane [10]

The epichlorohydrin (370 g, $4 \mathrm{~mol})$ dropwise was added to a solution consisting of methylcyclopentyl ketone (224 g, $2 \mathrm{~mol})$ and boron trifluoride ether $(5.6 \mathrm{~g}, 0.04 \mathrm{~mol})$ in constant stirring. The reaction temperature was maintained within the range of $35-40^{\circ} \mathrm{C}$. After that, the reaction mixture had been stirred for another 3 hours at a room temperature. The excess of epichlorohydrin was distilled off, and then the reaction mass was distilled in a vacuum. The yield of purposeful product was $89 \%$, B.p. $=45^{0} \mathrm{C} / 2$ mm.merc.c. ${ }^{1} \mathrm{H}-\mathrm{PMR}$ $\delta$ (ppm.) : $\left(\mathrm{CDCI}_{3}\right) 3.45-3.60(2 \mathrm{H}, \mathrm{m}), 3.25-4.20$ $(3 \mathrm{H}, \mathrm{m}), 1.20(3 \mathrm{H}, \mathrm{s}), 0.90-1.16(9 \mathrm{H}, \mathrm{m})$.

According to a similar methodology, the corresponding 2-methyl-2-cyclohexyl, 2cyclopentylidene and 2-cyclohexylidene-4chloromethyl-1,3-dioxolanes were obtained from epichlorohydrin and methylcyclohexyl ketone, cyclopentanone and cyclohexanone.

Synthesis of 2-methyl-2-cyclopenthyl-4methylene-1,3-dioxolane

The solution of $27 \mathrm{~g}(0.5 \mathrm{~mol})$ of sodium methylate in DMF $(100 \mathrm{ml})$ at a room temperature dropwise was added to a mixture consisting of $40.9 \mathrm{~g}$ ( $0.2 \mathrm{~mol})$ of 2-methyl-2cyclopentyl-4-chloromethyl-1,3-dioxolanes in the course of constant stirring. The mixture was stirred at the same temperature for 4 hours. Then water $(150 \mathrm{ml})$ was slowly added to the reaction mixture, after which it was extracted with ester $(200 \mathrm{ml})$. The organic layer was separated and dried with anhydrous $\mathrm{MgSO}_{4}$ while the solvent was distilled off. The residue was distilled at a low pressure. The yield of determined by a method of gas-liquid chromatography on chromatoghraph LKhM$8 \mathrm{MD}$, the kinetics of homopolymerization was studied by dilatometric method [9].

purposeful product (transparent liquid) $-90 \%$, B.p. $=52^{0} \mathrm{C} / 10 \mathrm{~mm}$.merc.c., ${ }^{1} \mathrm{H}-\mathrm{PMR}-\delta$ (ppm.) : $\left(\mathrm{CDCI}_{3}\right)$ 4.20-4.45 (2H, m), 3.80-4.20 (2H, m), $1.25(3 \mathrm{H}, \mathrm{s}), 0.92-1.16(9 \mathrm{H}, \mathrm{m})$.

According to a similar methodology, by interaction of 4-chloromethyl-2-methyl-2cyclohexyl, 2-chloromethyl-2-cyclopentylidene, 2-chloromethyl-2-cyclohexylidene-1,3-

dioxolanes with sodium methylate, 4methylene-2-methyl-2-cyclohexyl, 4methylene-2-cyclopentylidene and 4-methylene2-cyclohexylidene-1,3-dioxolanes were obtained, respectively.

\section{Polymerization of 4-methylene-2- substituted-1,3-dioxolanes}

The polymerization of synthesized monomers was carried out in sealed ampoules at $333 \mathrm{~K}$. A calculated number $(0,5 \mathrm{~mol})$ of monomer, dry benzene $(10 \mathrm{ml})$ and $\operatorname{AIBN}(0,5 \%$ from quantity of monomer) was loaded to an ampoule. Then for removal of the occluded air, the solution in the ampoules was first frozen, vacuumed for 10-15 min., and then unfrozen. This process was repeated several times. After that, the ampoule was frozen, filled with nitrogen, sealed and placed in a thermostat. The polymerization time varied depending on the type of monomer within 2-4 hours. After the specified time, the ampoule was cooled, opened and an equal quantity of solvent was added and the obtained polymer was planted in an appropriate precipitator (ester, alcohol or saturated hydrocarbon). The polymers purification was carried out by reprecipitation. The isolated polymers were dried in a vacuum at

333

K.

\section{Results and discussion}

As noted in the experimental part, 4methylene-1,3-dioxolanes (1-4) were synthesized by dehydrochlorination of chloromethyldioxolanes in the presence of sodium methylate in DMF solution at a room temperature. 


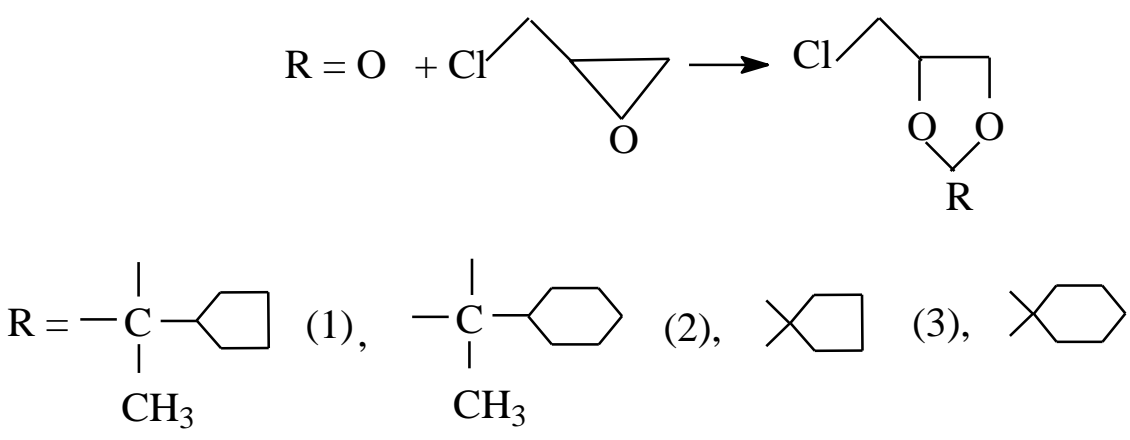

According to the data of disappearance of the absorption band in the chromatographic analysis the yields of fields of 900-1000, 1640-1650 cm compounds 1-4 were high $(82-85 \%)$. Their structure was confirmed by data of IR and PMR spectroscopy.

In the IR spectra of compounds 1-4 there were characteristic absorption bands referring to valence vibrations of $\mathrm{C}=\mathrm{C}$ bond in the field of $1645-1650 \mathrm{~cm}^{-1}$. The absorption bands in the fields of 1080-1090 and 1110-1130 $\mathrm{cm}^{-1}$ characterized the availability of ether bond of dioxolane cycle in their molecules. In the PMR spectra of compounds $\mathbf{1 - 4}$ the ratio of integral intensities of the signals at $\delta=4.30 \mathrm{ppm}$, protons (double bond) and $\delta=2.80 \mathrm{ppm}$. (protons $-\mathrm{OCH}_{2}$ group) was $3: 1$, that was possibly connected with superimposition of the signal of one proton of the methylene group on the expanded singlet of two olefin protons.

The polymerization of the synthesized monomers 1-4 was carried out in the presence of initiators AIBN (dinitrileazoisobutyric acid) and DTBP (ditertiary butyl peroxide) at various temperatures in mass and in benzene solution.

A comparison of IR spectra of the monomers and polymers derived from them showed that the main links of the macromolecular chain were linear structures formed as a result of simultaneous opening of the double bond and dioxolane cycle. Along with linear links in the chain of macromolecules, the formation of dioxolane cycle links as side groups was also observed. The availability of linear structural links in the chain of macromolecules was evidenced by the (deformation and valence vibrations of vinylidene groups) available in the spectra of the initial monomers and the appearance of a new absorption band in the field of $1735 \mathrm{~cm}^{-1}$ that characterized the ketone group. The availability of the absorption bands in the IR spectra of the obtained polymers in the fields of 1070-1080 $\mathrm{cm}^{-1}, 1100-1120 \mathrm{~cm}^{-1}$ characterized ether bonds of the dioxolane cycle.

The availability of cyclic and linear structural links (cyclolinear structure)in the chain of macromolecules also confirms the data of PMR spectra, which shows that all polymers have the above-proposed structure. This is evidenced by the appearance of resonance absorptions corresponding to protons of the methylene group, which is in the vicinity of the ketone group ( $\delta=3.45-4.20 \mathrm{ppm}$.).

Thus, the data of spectral analyses of the obtained homopolymers confirm that during polymerization of monomers 1-4, the macromolecules, which consist of both linear structural links with ketoester fragments (1,5 polymerization) and cyclic links with preservation of the dioxolane cycle $(1,2-$ polymerization) are formed.

Conditions of the polymerization and some characteristics of the obtained polymers are presented in Table 1.

Also, the influence of some parameters on the flow direction of the polymerization process was studied. 
Table1. Polymerizationof 2-substituted 4-methylene-1,3-dioxolanes in the various conditions.

\begin{tabular}{|c|c|c|c|c|c|c|}
\hline Compounds & $\begin{array}{l}\text { Initiator, } \\
\text { mol. } \%\end{array}$ & $\begin{array}{c}\text { Temperature, } \\
{ }^{\circ} \mathrm{C}\end{array}$ & $\begin{array}{l}\text { Polym. } \\
\text { time, } \mathrm{h}\end{array}$ & $\mathrm{MW}^{*} \cdot 10^{-3}$ & Yield, \% & $\begin{array}{c}\text { Degree of } \\
\text { opening }\end{array}$ \\
\hline \multirow{4}{*}{1} & AIBN. 5.0 & 60 & 20 & 4.8 & 28 & 58 \\
\hline & & 70 & 20 & 4.6 & 32 & 65 \\
\hline & DTBP. 5.0 & 110 & 25 & 4.5 & 53 & 71 \\
\hline & -"- & 120 & 25 & 4.4 & 57 & 76 \\
\hline \multirow{4}{*}{2} & AIBN. 5.0 & 60 & 20 & 5.2 & 31 & 62 \\
\hline & & 70 & 20 & 4.8 & 38 & 66 \\
\hline & DTBP. 5.0 & 110 & 25 & 4.6 & 44 & 73 \\
\hline & -"- & 120 & 25 & 4.5 & 62 & 78 \\
\hline \multirow{4}{*}{3} & AIBN. 5.0 & 60 & 20 & 5.4 & 38 & 81 \\
\hline & & 70 & 20 & 5.2 & 51 & 84 \\
\hline & DTBP. 5.0 & 110 & 25 & 5.0 & 58 & 88 \\
\hline & _“6 & 120 & 25 & 4.8 & 69 & 91 \\
\hline \multirow{2}{*}{4} & AIBN. 2.0 & 70 & 20 & 5.8 & 48 & 83 \\
\hline & DTBP. 2.0 & 120 & 25 & 5.2 & 76 & 92 \\
\hline
\end{tabular}

As follows from data of Table 1, the degree of the dioxolane cycle opening depends on polymerization temperature. With temperature rise a part of links with dioxolane cycle opening is increased.

The scheme of polymerization of the synthesized monomers can be presented as follows:

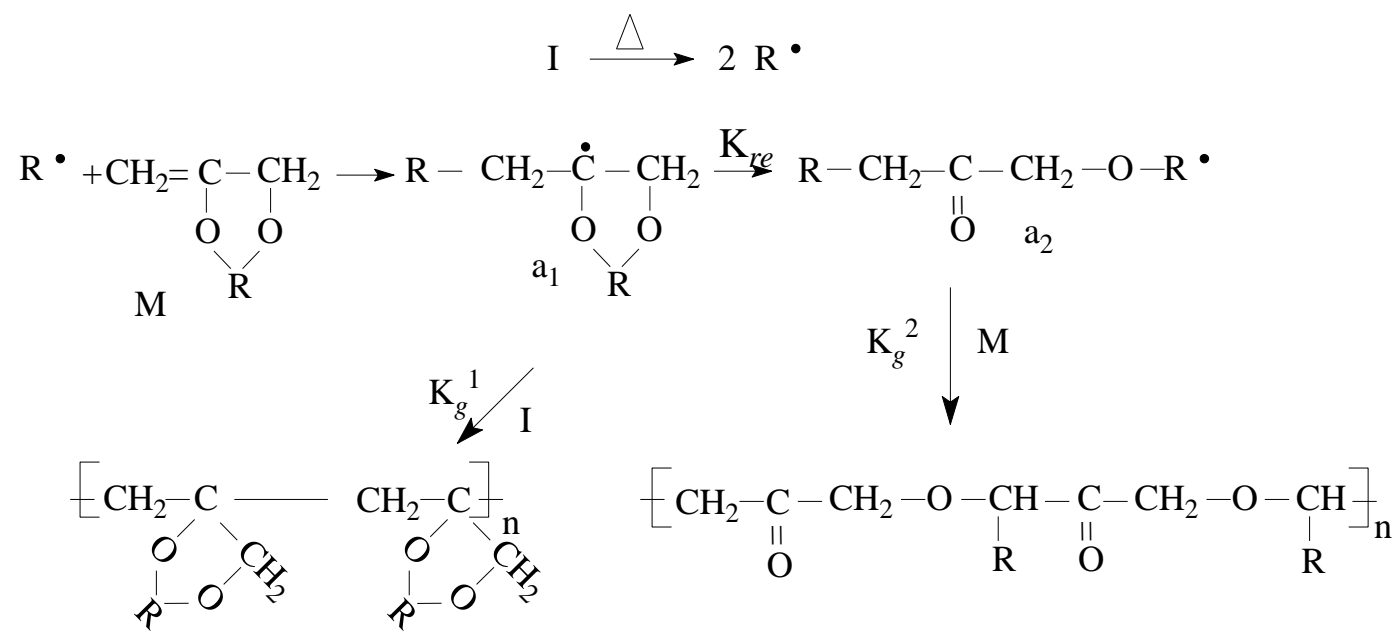

To reveal main regularities of the radical polymerization of the synthesized monomers 1 4 , the kinetics of the process for monomer 1 was studied. On the basis of the data obtained for initial stages of the polymerization where almost all series of experiments had a linear dependence of conversion on time, the reaction orders for the monomer and initiator were found.

The obtained results led to the expression for total polymerization rate.

The reaction order on initiator in

initiation of AIBN indicates to a bimolecular break of growing macromolecular chains. The reaction order value on monomer, less than one, is explained similarly to work [6], by availability of two different types of growing radicals in the system.

The activation energy of the polymerization corresponded to $5.84 \cdot 10^{4} \mathrm{~J} / \mathrm{mol}$.

During the polymerization of monomers 1-4 along with linear structural links in the chain of macromolecules, the formation of links containing dioxolane cycles was observed. 
It follows from the kinetic polymerization dioxolane cycles is expressed by the equation: scheme that the links formation rate with

$$
\frac{\mathrm{d}[\mathrm{DO}]}{\mathrm{dt}}=\left(K_{g}^{1}\left[a_{1}^{\cdot}\right]+K_{g}^{2}\left[a_{2}^{\bullet}\right]\right)[\mathrm{M}]-\mathrm{K}_{\mathrm{re}}\left[a_{1}^{\bullet}\right]
$$

The monomer consumption rate is expressed by the equation:

$$
-\frac{\mathrm{d}[\mathrm{M}]}{\mathrm{dt}}=\left(K_{g}^{1}\left[a_{1}^{\cdot}\right]+K_{g}^{2}\left[a_{2}^{\cdot}\right]\right)[\mathrm{M}]
$$

Dividing equation (1) into equation (2) fraction of linear $\left(f_{l}\right)$ and cyclic $\left(f_{c}\right)$ structural and substituting $a_{2}$ value and guided by the units are expressed by equations: principle of quasi-stationary process, the

$$
f_{c}=1-\frac{r_{\mathrm{r} \theta}}{r_{r \theta}+[\mathrm{M}]} \quad f_{l}=1-f_{c}=\frac{r_{r \theta}}{r_{r \theta}+[\mathrm{M}]} \quad \frac{1}{f_{i}}=1+\frac{[\mathrm{M}]}{r_{r \theta}}
$$

where $\mathrm{r}_{r \theta}=\frac{k_{r \theta}}{k_{g}^{1}}$.

If the polymer chains are long, the with linear structure $f_{l}$. The values calculated on polymer composition can be estimated by the basis of the obtained experimental results determination of the molar fraction of links with (according to PMR spectra) for the $f_{c}$ and $\mathrm{f}_{1 \text { is }}$ is dioxolane cycle $f_{c}$ or the molar fraction of links shown in Table 2.

\begin{tabular}{|c|c|c|c|c|c|c|}
\hline $\mathrm{T}, \mathrm{K}$ & $\begin{array}{c}{[\mathrm{M}]} \\
\mathrm{mol} / \mathrm{l}\end{array}$ & $\begin{array}{c}f_{c} \\
(\text { mol.frac. } \\
)\end{array}$ & $\begin{array}{c}f_{l} \\
\text { (mol.frac. } \\
\text { ) }\end{array}$ & $\begin{array}{c}\frac{1}{f_{l}} \\
(\text { mol.frac })^{-1}\end{array}$ & $\mathrm{~K}_{\mathrm{g}}^{1} / \mathrm{K}_{\mathrm{re}}$ & $r_{r e}=\frac{K_{r e}}{K_{g}^{1}}$ \\
\hline \multirow{3}{*}{333} & 0.82 & 0.18 & 0.82 & 1.22 & \multirow{3}{*}{0.101} & \multirow{3}{*}{9.90} \\
\hline & 1.64 & 0.25 & 0.75 & 1.33 & & \\
\hline & 3.28 & 0.32 & 0.68 & 1.47 & & \\
\hline \multirow{3}{*}{343} & 0.82 & 0.16 & 0.84 & 1.19 & \multirow{3}{*}{0.065} & \multirow{3}{*}{15.38} \\
\hline & 1.64 & 0.20 & 0.80 & 1.25 & & \\
\hline & 3.28 & 0.26 & 0.74 & 1.35 & & \\
\hline \multirow{3}{*}{353} & 0.82 & 0.14 & 0.86 & 1.16 & \multirow{3}{*}{0.048} & \multirow{3}{*}{20.83} \\
\hline & 1.64 & 0.22 & 0.82 & 1.22 & & \\
\hline & 3.28 & 0.27 & 0.78 & 1.28 & & \\
\hline
\end{tabular}

Table 2. Dependence of the polymer composition on concentration of methylenedioxolane at various temperatures

The value found for the rearrangement constants $\left(\mathrm{r}_{r_{\theta}}\right)$ means that $k_{r_{\theta}}>k_{g}^{1}$ and was agreed with the structure of the polymer chain. Thus, as a result of competing reactions monomolecular rearrangement and intermolecular chain growth, the polymers containing both links with side dioxolane groups and links with linear structureare formed. The values found for $r_{r \theta}$ showed that the elementary links with linear structure prevail. 


\title{
References
}

1. Nuyken O., Pask S. Ring-opening polymerization - An introductory review. Polymers, 2013, vol. 5, pp.361-403.

2. Hayakava K., Matsuoka S., Suzuki M. Ringopening polymerization of donor-acceptor cyclopropanes catalyzed by Lewis acids. Polym. chem., 2017, vol. 8, issue 25, pp. 3841-3847.

3. Takahashi N., Yamada S., Sudo A., Endo T. Synthesis and radical ring-opening polymerization of vinylcyclopropanes derived from amino acids with hydrophobic moieties. Journal of polymer science, part A: Polymer chemistry. 2017, vol. 55, issue 21, pp. 3515-3528.

4. Paul S., Zhu Y., Romain Ch. et.al. Ringopening copolymerization (ROCOP): Synthesis and properties of polyesters and polycarbonates. Chem. Commun, 2015, vol. 51, pp. 6459-6479.

5. Sanda F., Endo T. Radical Ring-Opening Polymerization. J. Polym. Sci., Part A:Polym. Chem., 2001, vol. 39, pp. 265-276.

6. Guliyev A., Shahnazarli R., Ramazanov G.
Ring-opening polymerization of vinylcyclopropanes. In book: "Highperformance polymers for Engeering based Composites" Apple Academic Press, inc. USA, 2016, chapter 2, p.13-27

7. Ramazanov G.A. Free-radical ring-opening polymerization of methylenedioxolanes. Scientific news, SSU, Sumgait, 2004, no. 3, pp. 46-57. (In Azerbaijan).

8. Morariu S., Bercea M. Synthesis, characterization and conformational transitions in copolymers of 2-(ochlorophenyl)-4-methylene-1,3-dioxolane with vinyl monomers. Polymer, 2004, vol. 53, pp.1253-1258.

9. Kuznetsov E.V., Dibgun S.M., Budarina L.A., Abbakumova N.I., Kurenkov V.F. Practicum on chemistry and physics of polymers. Moscow: Khimiya Publ., 1977, pp. 17-18

10. Yusifli F., Ramazanov G., Guliyev A. Synthesis and free-radical thiilation (addition of thiopenols) of unsaturated cyclic acetals. J.Chem.Chem.Eng. 2019, vol.13, pp. 76-81.

\section{TSIKLOALKIL ӘVӘZLI METILENDIOKSOLANLARIN SINTEZİ VӘ RADIKAL POLIMERLOŞMOSI}

\section{F.X. Yusifli, Q.Ә. Ramazanov, A.M. Quliyev}

\author{
${ }^{1}$ Sumqayut Dövlat Universiteti \\ AZ 5008, Sumqayıt, 43-cü mahalla, e-mail:feride-yusifli@mail.ru \\ ${ }^{2}$ AMEA Polimer Materiallarl Institutu \\ AZ 5004, Sumqayıt, S.Vurğun küç.,124, e-mail:abasgulu@yandex.ru
}

Bir sıra doymamış 4-metilen-1,3-dioksolanlar sintez edilarək xarakterizo olunmuş vo onların radikal inisiatorlar iştirakında kütlado vo məhlulda polimerloşməsi aparılmışdır. Alınmış polimerlarin IQ- va PMR-spektrlarinin naticalari ila müayyan edilmişdir ki, sintez edilmiş monomerlarin homopolimerlaşmasi ham metilen ikiqat rabitasi va dioksolan halqasinin birga iştirakı ila ketoefir fraqmentli xatti quruluşlu manqaların, hom do yalnız metilen qrupunun iştirakı ilo yan qruplar kimi dioksolan tsikllari saxlayan manqaların alınmast ilo gedir. Müəyyən edilmişdir $k i$, alınan xatti vo tsiklik quruluşlu elementar manqaların nisbati monomerin qatıliğından vo polimerlaşmə temperaturundan asılıdır. Göstərilmişdir ki, polimerlaşmənin məhlulda aparıldiğı halda monomerin qatılığının artırılması tsiklik quruluşlu elementar manqaların payını artırır, lakin polimerləşmənin bütün hallarında xətti quruluşlu manqaların payı tsiklik quruluşdan üstün olur. Göstərilmişdir ki, polimerləşmə temperaturunun artırllması makromolekul zəncirində dioksolan tsiklinin qırllması ilo alınan manqaların payının artmasına sabəb olur. Polimerlaşmə prosesinin kinetikası öyrənilmiş, monomerə va inisiatora görə reaksiyanın tərtibi müzyyənləşdirilmiş, həmçinin 
prosesin aktivlaşmə enerjisi hesablanmışdır. Reaksiyanın monomerə görə tərtibinin vinil monomerlarinin polimerlaşməsi ila müqayisadə aşă̆l olması sistemdə iki müxtalif tip zancirin uzanmasını aparan radikalın olması vo onların zoncirin qırılma reaksiyasında iştirakı ilo alaqadardır.

Açar sözlor: metilendioksolan, sintez, radikal polimerləşmə, inisiator, kinetika, tsiklin qırılması ilo polimerlaşma.

\title{
СИНТЕЗ И РАДИКАЛЬНАЯ ПОЛИМЕРИЗАЦИЯ ЦИКЛОАЛКИЛЗАМЕЩЕННЫХ МЕТИЛЕНДИОКСОЛАНОВ
}

\author{
Ф.Х. Юсифли', Г.А. Рамазанов ${ }^{1}$, А.М. Гулиев ${ }^{2}$ \\ ${ }^{1}$ Сумгаитский государственный университет
}

AZ 5008, Cумгаит, квартал 43, e-mail: feride-yusifli@mail.ru

${ }^{2}$ Институт полимерных материалов Национальной АН Азербайджана

AZ 5004, Сумгаит, ул. С.Вургуна, 124, e-mail:abasgulu@yandex.ru

Синтезирован и охарактеризован ряд непредельных 4-метилен-1,3-диоксоланов и проведена их полимеризация в присутствии радикальных инициаторов как в массе, так и в растворе. Данныли ИК- и ПМР- спектров полученных полимеров установлено, что гомополимеризация синтезированных мономеров протекает как с одновременным участием метиленовой двойной связи и диоксоланового цикла с образованием линейных структурных звеньев с кетоэфирными фрагментами, так и только с участием метиленовой группы с образованием звеньев с диоксолановыми цуиклами в качестве боковых групп. Выявлено, что соотношение образуюшихся линейных и ичиклических структурных звеньев зависит от концентрации мономера и температуры полимеризации. Установлено, что с повышением концентрации мономера при проведении полимеризации в растворе доля циилических элементарных звеньев увеличивается, но во всех случаях полимеризачии доля линейных звеньев преобладает над ичилическими. Найдено, что с повынением температуры полимеризации доля звеньев с раскрытием диоксоланового иикла в макрочепи увеличивается. Изучена кинетика прочесса полимеризации, выявлен порядок реакции по мономеру и инициатору, а также вычислена энергия активация процесса. Меньшее значение порядка реакции по мономеру по сравнению с полимеризацией виниловых мономеров объясняется наличием в системе двух разных типов растущих радикалов и участие их в реакциях обрыва изепи.

Ключевые слова: метилендиоксолан, синтез, радикальная полимеризация, инициатор, кинетика, полимеризация с раскрытием цүикла. 